Çukurova Üniversitesi Mühendislik Mimarlık Fakültesi Dergisi, 29(1), 173-191 ss., Haziran 2014

Çukurova University Journal of the Faculty of Engineering and Architecture, 29(1), pp. 173-191, June 2014

\title{
Bayat-Bolvadin (Afyonkarahisar) Arasındaki Bölgenin Stratigrafisi
}

\author{
Şenol ŞAHİN ${ }^{1}$, Ulvi Can ÜNLÜGENÇ ${ }^{* 2}$ \\ ${ }^{1}$ MTA, Doğu Akdeniz Bölge Müdürlü̆̈̈̈, Adana \\ ${ }^{2} C ̧ . \ddot{U}$., Mühendislik-Mimarlık Fakültesi, Jeoloji Mühendisliği Bölümü, Adana
}

\section{Özet}

Afyon kuzeybatısında Bayat ve Bolvadin ilçeleri arasında bulunan çalışma alanının temelini Geç Prekambriyen yaşlı İhsaniye formasyonu oluşturmaktadır. İhsaniye formasyonu üzerine taban konglomerası ile başlayan Permiyen yaşı Eldeş formasyonu açısal uyumsuzluk ile gelmektedir. ErkenOrta Triyas yaşı Kıyır formasyonu, tabanda rekristalize kireçtaşı çakıllarının yaygın olarak izlendiği bir seviye ile Eldeş formasyonu üzerine uyumsuz olarak gelmektedir. Kıyır formasyonu üzerinde ise uyumlu ve geçişli dokanakla Orta Triyas-Kretase yaşı Gökçeyayla formasyonu bulunmaktadır. Gökçeyayla formasyonu, tabanda rekristalize kireçtaşı-şist ardalanmasından oluşan Paşadağ üyesi ve üst seviyelerde dolomit ve dolomitik kireçtaşının egemen olduğu Karacaçal Tepe üyesinden oluşmaktadır. Çalışma alanında, bu temel birimler üzerine en altta Erken Miyosen yaşlı Beşsaray formasyonu ile başlayan örtü birimleri uyumsuzlukla gelmektedir. Beşsaray fomasyonu üzerine uyumlu olarak gelen Erken MiyosenPliyosen yaşlı Akpınar formasyonu ile Erken Miyosen-Pliyosen yaşlı Seydiler ignimbiritleri birbirleri ile yanal ve düşey geçişlidir. Örtü birimleri birbirleri ile uyumsuz dokanaklı Pliyosen yaşlı Yapılıkale Tepe volkanitleri ve Pliyosen yaşı Erdemir formasyonu ile Kuvaterner yaşlı alüvyonlarla sonlanmaktadır.

Torid-Anatolid kuşağının kuzeyinde yer alan çalışma alanı, KD-GB ve D-B yönlü sıkışma etkisi altında kalmıştır. Bundan dolayı, çalışma alanında bu sıkışmanın etkisiyle yaklaşık KB-GD ve K-G uzanımlı kıvrım eksenleri oluşmuş olup, K-G doğrultulu bindirmeler ile 3 tektonik dilim oluşmuştur. Temel birimlerden derlenen örneklerin petrografik analiz sonuçlarına göre edinilen metamorfik mineral parajenezleri bölgede yüzeyleyen temel birimlerin yeşilşist metamorfizmasına maruz kaldığını göstermektedir.

Anahtar Kelimeler: Afyon zonu, Stratigrafi, Prekambriyen, Eldeş formasyonu

\section{Stratigraphy of the Area Between Bayat-Bolvadin (Afyonkarahisar)}

\begin{abstract}
Prekambrian age İhsaniye formation forms the basement unit of the studied area which is located to the northwest of Afyon between Bayat and Bolvadin district. Permian age Eldeş formation, which starts with basal conglomeratic levels, rests on the İhsaniye formation with angular unconformity. Early-Middle Triassic age Kıyır formation that has widespread recrystallized limestone pebbles at the base samples

\footnotetext{
* Yazışmaların yapılacağı yazar: Ulvi Can ÜNLÜGENÇ, Ç.Ü., Mühendislik Mimarlık Fakültesi, Jeoloji
} Mühendisliği Bölümü, Adana. ulvican@cu.edu.tr
\end{abstract}


unconformaby covers the Eldeş formation. Middle Triassic-Cretaceous age Gökçeyayla formation transitionally and concordantly rest on the Kıyır formation. Gökçeyayla formation comprises Paşadağ member that has recrystallized limestone-schist alternations at the base and Karacaçal Tepe member dominated with dolomitic and dolomitic limestone on the upper part of the formation. Early Miocene age Beşsaray formation that form the lower part of cover units unconformably overlies the basement units in the studied area. Early Miocene-Pliocene age Akpınar formation and Early Miocene-Pliocene age Seydiler ignimbrites that has lateral and vertical contact relationship with each other conformably rest on the Beşsaray formation. Cover units ends with Pliocene age Yapılıkaya volcanites, Pliocene age Erdemir formation which has unconformable contact relationship with each other and Quaternary age alluviums. The study area located on the north of Tauride-Anatolides belt is remained under NE-SW and E-W trending compressional regime. Therefore, approximately NW-SE and N-S trending folds axes and N-S trending 3 tectonic slices occurred due to this compressional tectonic regime in the study area. According to the determined metamorphic mineral paragenesis obtained from the petrographical analyses of the rock samples collected from the basement rock units indicate that the outcrops of basement rocks were exposed under the green schist metamorphism conditions in the studied area.

Keywords: Afyon Zone, Stratigraphy, Precambrian, Eldes formation

\section{GíRIȘ}

Afyonkarahisar iline bağlı Bayat ilçesi güneyi ve Bolvadin ilçesi kuzeyinde yer alan inceleme alanı, 1/25 000 ölçekli Afyon K25b2-b3 ve Afyon K26a4 paftaları içerisinde yer alan, yaklaşık $300 \mathrm{~km}^{2}$, lik bir alanı kapsamaktadır (Şekil 1). İnceleme alanı Neo-Tetis Okyanusu'nun kapanması ile birlikte Anatolid-Torid Platformu'nun kendi içinde ekaylı yapılar kazanarak, farklı yaş ve metamorfik fasiyeslere sahip kaya birimlerini içermektedir. Yeşilşist fasiyesinde Paleosen'de metamorfizmaya uğrayan Afyon Zonu çalışma alanı dışında yer alan, Anatolid-Torid Platformu'nun kuzey kenarına ait mavişist metamorfizması gösteren Kampaniyen'de metamorfizmaya uğrayan Tavşanlı Zonu tarafindan tektonik olarak üzerlenmektedir (Șekil 2). İnceleme alanı dıșında Afyon Zonu, Menderes Masifi üzerine tektonik dokanakla gelmektedir [1].

İnceleme alanında temelde Geç Prekambriyen yaşlı İhsaniye formasyonu oluşturmakta ve üzerine Permiyen yaşlı Eldeş formasyonu açısal uyumsuzlukla gelmektedir. Erken-Orta Triyas yaşlı Kıyır formasyonu uyumsuz olarak Eldeş formasyonunu üzerlemekte ve üzerine geçişli olarak Orta Triyas-Kretase yaşlı Gökçeyayla formasyonu gelmektedir. İnceleme alanında tüm yaşlı birimler üzerine uyumsuz olarak Neojen yaşlı çökeller ve volkanik birimler gelmektedir. Erken-Orta Miyosen yaşlı Beşsaray formasyonu, Orta Miyosen-Pliyosen yaşlı Akpınar formasyonu ve aynı yaşlı Seydiler ignimbiritleri, Pliyosen yaşlı

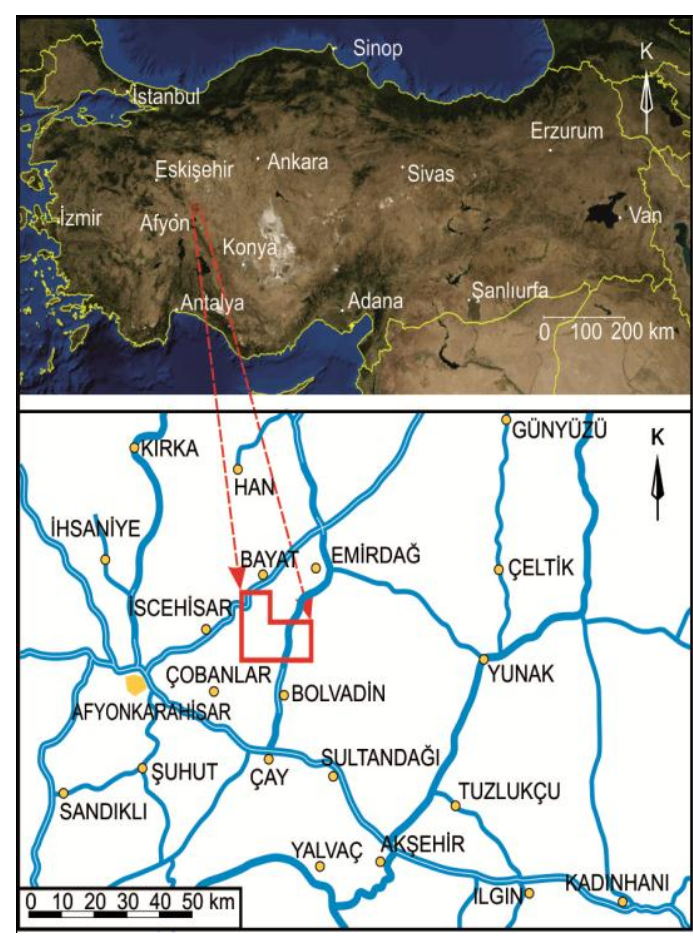

Şekil 1. İnceleme alanının yer bulduru haritası. 
Yapılıkale Tepe volkanitleri, Pliyosen yaşlı Erdemir formasyonu ve Kuvaterner yaşlı alüvyonlar bölgede yüzeyleyen en genç birimlerdir.

\section{ARAȘTIRMA BULGULARI}

\subsection{Bölgesel Jeoloji}

İnceleme alanı, Özgül, [2] tarafindan Bolkardağı Birliği, Şengör ve Yılmaz, [3] tarafindan Anatolid-Torid Platformu, Okay ve Tüysüz, [4] tarafından Afyon Zonu olarak tanımlanan bölgede bulunmaktadır (Şekil 2). Bolkardağı Birliği Orta Devoniyen-Erken Tersiyer yaş aralığındaki yeşilşist metamorfizması gösteren kaya birimlerini kapsamaktadır. Çalışma alanı Afyon Zonu [5], Bolkardağ Kuşağı [6] ve Kütahya-Bolkar Kuşağ [7] olarak tanımlanan kuşak içinde bulunmaktadır.

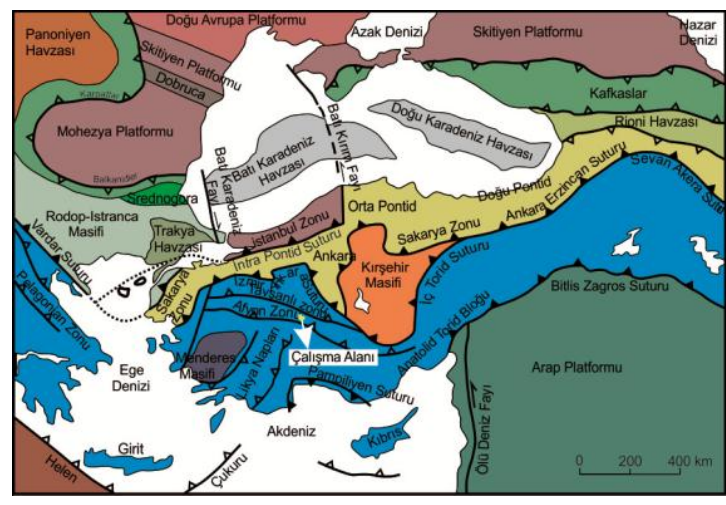

Şekil 2. Türkiye ve yakın çevresinin tektonik konumu [4]'den alınmıştır.

İnceleme alanı ve civarında yüzeyleyen birimlerin, Menderes Masifi ve Tavşanlı Zonu içerisinde yer alan birimler ile benzer yaş ve litolojik özelliklere sahip oldukları görülmüştür.

Okay, Afyon Zonu'nun doğuda Bolkardağ bölgesine kadar uzanan ve batıda Menderes masifine ait gnaysların örtüsünü oluşturan, Toroslar'a ait tipik bir Paleozoyik-Mesozoyik istif olduğunu belirtmektedir [5]. Çalışmacı, Afyon Zonu'nun tabanda 1500 metre'den fazla kalınlığa ulaşan metakumtaşı, metasilttaşı ve seyrek olarak metabazit ve rekristalize kireçtaş1 tabakaları içeren kuvarsitlerden oluştuğunu ifade etmektedir.

Özcan ve ark., çalışma alanı ve civarında yaptıkları çalışmalarda tabanda Karbonifer-Permiyen yaşlı İhsaniye Metamorfik Karmaşığı şeklinde tanımladıkları istif üzerine açısal uyumsuzlukla Mesozoyik yaşlı birimlerin geldiğini belirtmektedirler [8].

Tolluoğlu ve ark., yapmış oldukları çalışmada inceleme alanının tabanında Alt ve Üst Metamorfitler adını verdikleri Pre-Devoniyen yaşlı birimlerin olduğunu ve Orta-Geç DevoniyenPermiyen yaşlı Değirmendere kireçtaşlarının uyumsuzlukla geldiğini, bu birimlerinde üzerine Mesozoyik yaşlı birimlerin uyumsuzlukla geldiğini belirmişlerdir [9].

Göncüoğlu, çalışma alanı ve civarında yapmış oldukları çalışmada en altta Pre-Permiyen yaşlı bir Temel biriminin olduğunu belirtmiştir. $\mathrm{Bu}$ temel üzerine ise uyumsuz olarak Permiyen yaşlı Eldeş formasyonu ile yine altındaki birimler üzerine uyumsuzlukla gelen Erken Triyas yaşlı Ardiçlı, Orta Triyas-Jura yaşlı Loras ve Geç Jura-Kretase yaşlı Midos formasyonlarını tanımlamıştır [10].

Candan ve Çetinkaplan, Pan-Afrikan Temel olarak tanımladıkları birimin, Triyas yaşlı birimler tarafından uyumsuz olarak üzerlendiğini belirtmektedirler [11].

Gürsu ve Göncüoğlu, Afyon civarında yapmış oldukları çalışmada Afyon Temel Karmaşı̆̆ olarak tanımladıkları başlıca kuvars-albit-granatbiyotit şistlerden oluşan birimin yaşının 543 my olduğunu saptamışlardır. Çalışmacılar ayrıca bölgede Afyon Temel Karmaşı̆̆ı'nı uyumsuz olarak üzerleyen ve metakonglomeralar ile başlayıp, klorit-kuvarsşistler ile ardalanmalı kuvarsitlerden oluşan Orta Devoniyen (?) yaşlı Çalışlar formasyonunu tanımlamışlardır [12].

\subsection{Stratigrafi}

İnceleme alanında Prekambriyen-Kuvaterner yaş aralığını kapsayan 10 adet formasyon ayırtlanarak haritalanmış (Şekil 3) ve inceleme alanının genelleştirilmiş stratigrafik kesiti 


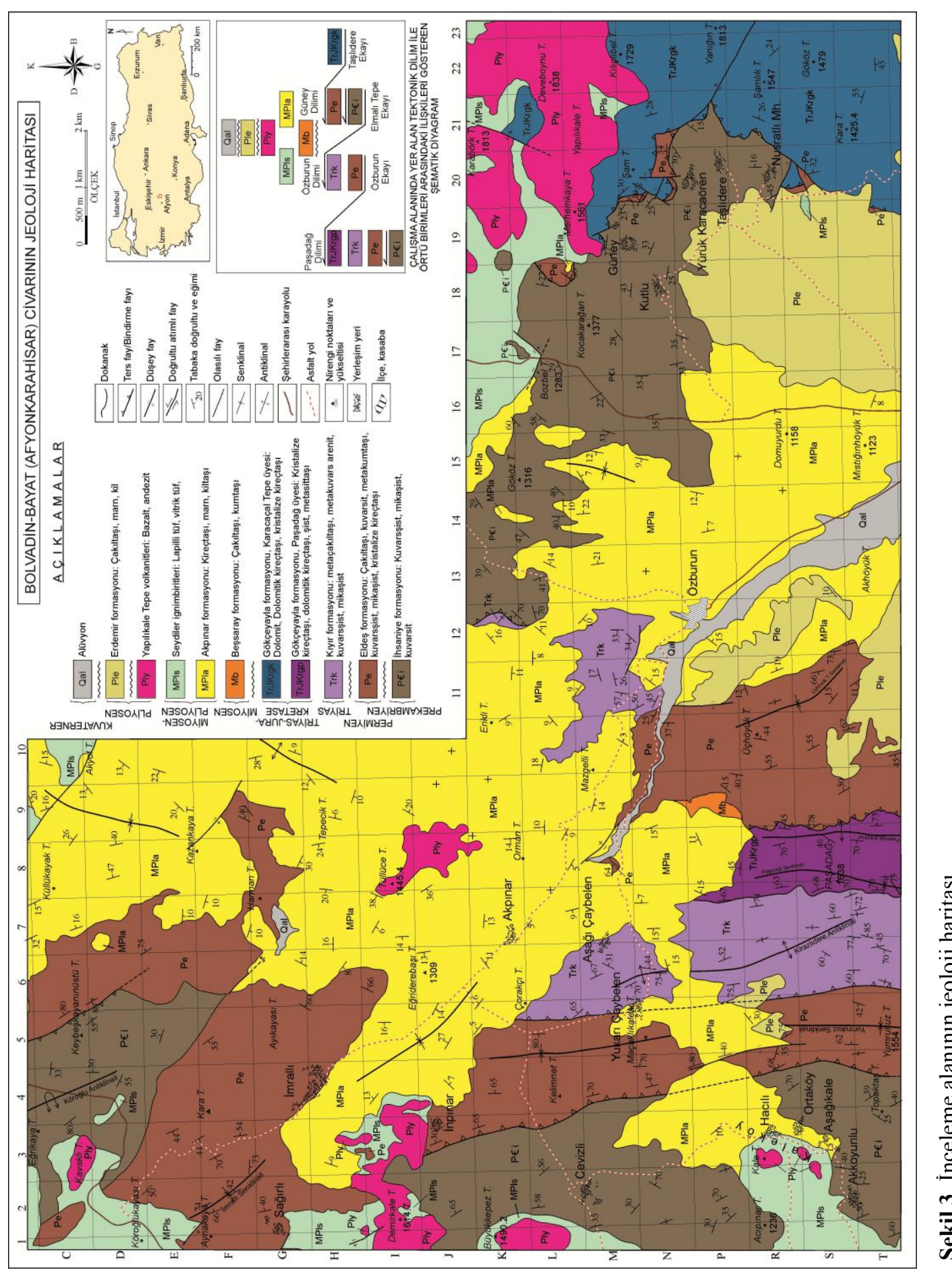




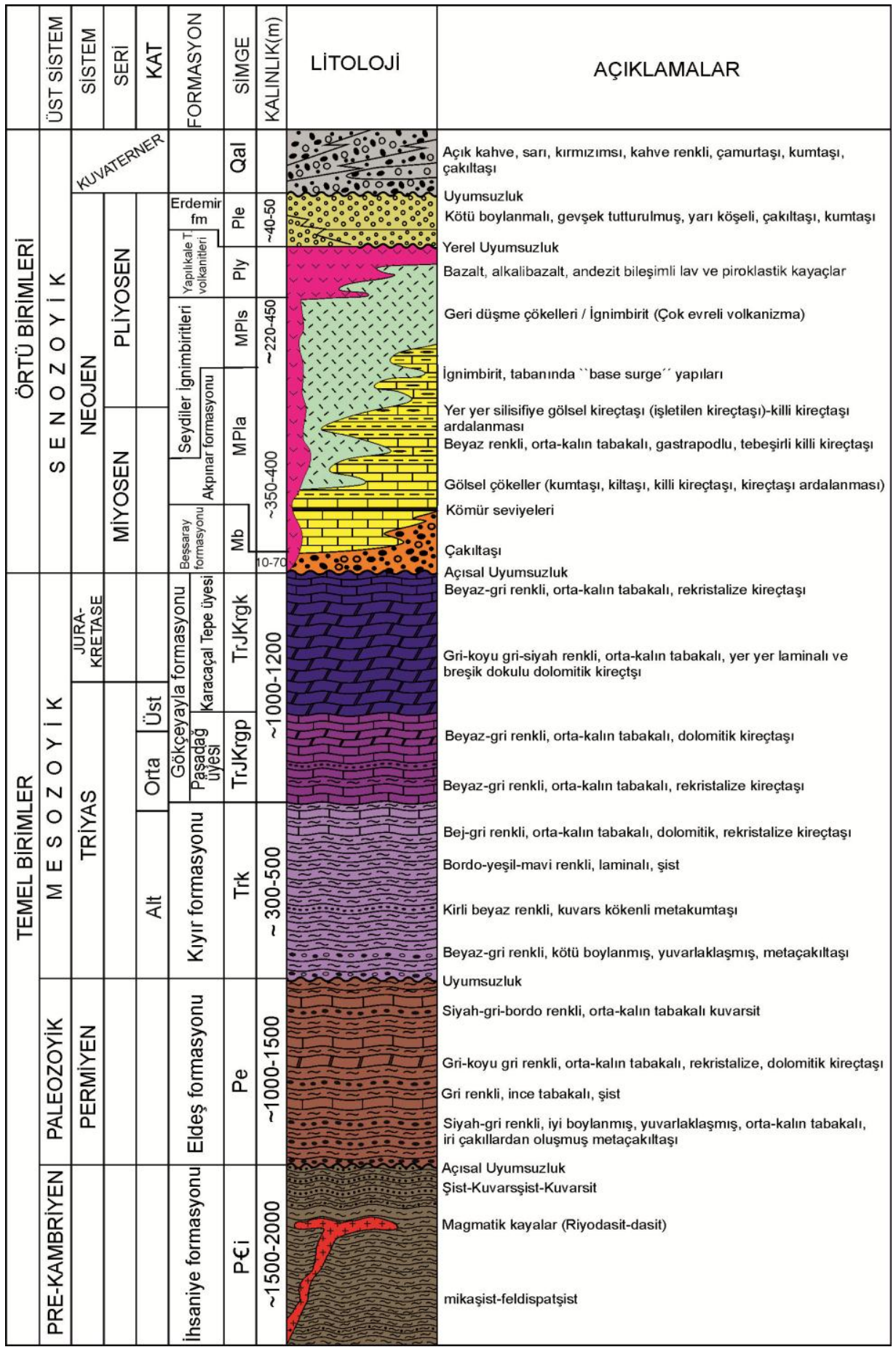

Şekil 4. Çalışma alanının genelleştirilmiş stratigrafik kesiti. 
çıkarılmıştır (Şekil 4). İnceleme alanında ayırtlanan tüm birimler Şengör ve Yılmaz [3] tarafindan tanımlanan Anatolid-Torid Platformu içinde, daha önceki araştırmacılar tarafından tanımlanan birimler ile karşılaştırılarak birliktelik sağlanmaya çalışılmıştır.

$\mathrm{Bu}$ çalışmada Prekambriyen-Kretase yaş aralığındaki metamorfik birimler Temel Birimler, Kretase sonrası oluşan birimler ise Örtü Birimleri adı altında incelenmiştir.

\subsubsection{Temel Birimler}

İnceleme alanının temelini Prekambriyen-Kretase zaman aralığında çökelmiş Temel Birimler oluşturmaktadır. İnceleme alanında geniş yüzeylemeler sunan ve taban kesimi izlenemeyen Geç Prekambriyen yaşlı İhsaniye formasyonu yer almaktadır. İhsaniye formasyonu üzerine uyumsuz olarak Permiyen yaşlı Eldeş formasyonu gelmektedir. Erken-Orta Triyas yaşlı Kıyır formasyonu Permiyen yaşlı Eldeş formasyonu üzerine açısal uyumsuzlukla gelmektedir. Kıyır formasyonu Orta Triyas-Kretase yaşlı Gökçeyayla formasyonu içinde tanımlanan ve haritalanan Erken-Orta Triyas yaşlı Paşadağ üyesine uyumlu ve geçişli olarak geçmektedir. İnceleme alanının K-KD kesimlerinde çoğunlukla, Geç Prekambriyen yaşlı temel üzerine Orta TriyasKretase yaşlı Gökçeyayla formasyonu içinde değerlendirilen Karacaçal Tepe üyesi tektonik konumlu olarak gelmektedir.

\subsubsection{1. İhsaniye Formasyonu (PEi)}

Başlica kuvarsşist, mikaşist ve kuvarsit ardalanmasından oluşan birim ilk kez bu çalışmada İhsaniye formasyonu adı altında incelenmiştir. Birim, Metin ve ark. [13] tarafindan Afyon Metamorfitleri içinde değerlendirilmiştir. Ayrıca, formasyon; Özcan ve ark. [8] tarafindan İhsaniye Metamorfik Karmaşı̆̆ı şeklinde tanımlanmış olup, Candan ve ark. [14] tarafindan ise Alt topluluk (Pan-Afrikan Temel) olarak kabul edilmiştir. Çalışma alanı içinde Gürsu ve Göncüoğlu [12] tarafından yapılan çalışmalarda ise birim Afyon Temel Karmaşığı olarak tanımlanmıştır. Formasyonun tip kesit yeri Akkoyunlu Mah. (S2),
Soğuklu Dere (T1)-Yumrukuz Tepe (T4) arasında kalan alandır. (Başlangıç:315940-4296240; Bitiş:318480- 4249246). Formasyon arazi gözlemlerinde koyu gri, siyah, yer yer yeşil, demiroksitli seviyelerde kırmızımsı olarak izlenmektedir.

İhsaniye formasyon başlıca kuvarsşist, mikaşist ve çok az oranda metakumtaşlarından oluşmaktadır. Formasyonun geniş bir yayılım gösterdiği Akkoyunlu Mah. (S2) doğusunda yapılan örnekleme çalışması ile derlenen 23 adet örneğin 18'i kuvarsşist, 4'ü mikaşist ve 1 tanesinde kuvarsit olarak tanımlanmıştır. Şistler içerdiği kuvars miktarına bağlı olarak dayanımlı, belirgin şistoziteye sahip olarak izlenmekte olup, metamorfizmanın etkisiyle yaygın segrege kuvars taneleri ve kuvars bantları içermektedir. Formayonun üst seviyelerinde yaygın olarak görülen feldispatşistler belirgin rengi ile tanınmaktadır.

Çalışma alanı içinde gözlenmeyen, ancak İscehisar İilçesi civarında Gürsu ve Göncüoğlu [12] tarafından yapılan çalışmalarda saptanan porfiritik granitoid ve mikro-gabroyik oluşumlarının varlığ bilinmektedir.

Formasyonu oluşturan kayaçlar geçirdikleri metamorfizma sonucu belirgin bir yönlenme kazanmışlar, gelişen tektonik unsurlar sonucu mikro kıvrımlanma göstermektedirler.

Formasyondan derlenen örneklerin, Jeo. Yük. Müh. Meltem Kadınkız (MTA) tarafından yapılan petrografik kayaç tanımlamaları sonucunda; andaluzit kuvars mikaşist, biyotit kuvarsşist, epidot plajiyoklaz mika kuvarsşist, epidot muskovit kuvarsşist, feldispat muskovit kuvarsşist, mika kuvarsşist, mika feldispat kuvarsşist, muskovit kuvarsşist, muskovit feldispat kuvarsşist, klorit muskovit feldispat kuvarsşist, klorit mika kuvars feldispatşist, klorit kuvars mikaşist, klorit serizit (muskovit) kuvarsşist, kuvars mikaşist, kuvarsit, metamorfik kayaçları saptanmıştır.

Çalışma alanında geniş alanlar kapsayan İhsaniye formasyonunun tabanı kesimi çalışma alanı içinde görülmemekte olup, üzerine tabanda çakıltaşları ile 
başlayan Eldeş formasyonu açılı uyumsuzlukla gelmektedir. Bu dokanak, bölgede meydana gelen tektonik hareketler nedeniyle çoğunlukla tektonik olarak izlenmektedir. Kivrımlı bir yap1 sunan formasyon kalınlığının 1500-2000 m civarında olduğu düşünülmektedir.

Gürsu ve Göncüoğlu [12], Afyon civarında yapmış oldukları çalışmada Afyon kuzeyinde diğer bölgelere göre çok fazla granitik dayklar olduğunu, granitik daykların uzunluklarının $50 \mathrm{~m}-10 \mathrm{~km}$, kalınlığının ise $50 \mathrm{~cm}-25$ metre arasında değiştiğini belirtmişlerdir. Çalışmacılar metasedimanter birimler içine sokulum yapan granitik dayklardan elde ettikleri ${ }^{207} \mathrm{~Pb} /{ }^{206} \mathrm{~Pb}$ zirkon yaşlarının $542 \mathrm{My}$ olduğuna dayanarak, metasedimanter birimlerin Geç Prekambriyen yaşlı olduğunu belirtmişlerdir.

Bu çalışmada İhsaniye formasyonu olarak tanıtılan birim, Gürsu [15] tarafından Sandıklı bölgesinde tanımlanan Güvercinoluk formasyonu ile deneştirilebilir.

\subsubsection{Eldeş Formasyonu ( $\mathrm{Pe})$}

İlk kez Özcan ve ark. [7] tarafindan tanımlanan Eldeş formasyonu, Eren [16] tarafindan tanımlanan Derbent formasyonu ile benzer özellikler göstermektedir. Formasyonun tabanında bulunan metaçakıltaşları Tolluoğlu ve ark. [9] tarafindan Deliktaş metakonglomerası adı altında incelenmiştir. Gürsu ve Göncüoğlu [12] ve Göncüoğlu [17] Afyon civarında yapmış oldukları çalışmada formasyonu aynı adla isimlendirmişlerdir. Adını Konya-Ilgın güneyinde yer alan Eldeş köyünden alan formasyon başlica metaçakıltaşı, şist ve rekristalize kireçtaş1 ardalanmasından oluşmaktadır.

Eldeş formasyonunun tip kesit yeri çalışma alanı dışında kalan Konya-Ilgın ilçesinin Eldeş köyü güneyindedir. İnceleme alanı içinde Yumrukuz Tepe (T4), Üçhöyük Tepe (R10) ve İmrallı Köyü (H4) kuzey kesimleri formasyonun başvuru kesit yerleridir.

Eldeş formasyonu tabanda iyi yuvarlaklaşmış, kötü boylanmalı, metamorfizmanın etkisiyle belli bir yönde yönlenmiş, başlıca kuvarsit çakıllarından oluşan metaçakıltaşı seviyeleri ve gri renkli, içinde yer yer beyaz kuvars çakılları içeren, şistozite özelliği gösteren şistler ile ardalanmalı olarak izlenmektedir.

Eldeş formasyonunun taban kesimlerinde gözlenen değișik renk ve boyutlardaki $(\sim 1-20 \mathrm{~cm})$ çakıllardan alınan örneklemelerin petrografik incelemeleri sonucu köken olarak kuvars arenitlerden türediği, karmaşık (girift) ve granoblastik dokulu olduğu, bol miktarda kuvars, az miktarda mika mineralleri, serizit, klorit, aksesuar mineraller olarak sfen, turmalin, zirkon ve opak minerallerinden oluştuğu saptanmıştır. Formasyonun tabanını oluşturan çakılların İhsaniye formasyonu içinde bulunan kuvarsit seviyelerinden ve/veya çalışma alanının kuş uçuşu yaklaşık $20 \mathrm{~km}$ batı kesimindeki İscehisar (Afyon) ilçesi, Çalışlar köyü civarında Gürsu ve Göncüoğlu [12] tarafindan tanımlanan Devoniyen yaşlı Çalışlar formasyonundan türediği söylenebilir.

Eldeş formasyonu üst seviyelere doğru yeşil, gri renkli şist, beyaz-gri-siyah renkli orta kalın tabakalı kuvars arenit, ince-orta kalın tabakalı, gri renkli, fosilli kristalize kireçtaşı ardalanması ile devam etmektedir. Kireçtaşları metamorfizma etkisi ile rekristalize olduklarından dolayı fosil tanımlaması yapılamamıştır. Formasyonun taban kesimi çakıltaşı-şist ardalanması ile tanımlanırken orta ve üst seviyeleri ise rekristalize kireçtaşı-şist ardalanması şeklinde tanımlanmaktadır. Rekristalize kireçtaşları şistler içinde merceksel şekilde kıvrımlı ve kırıklı olarak izlenmektedir. Orta seviyelerde şistler içinde ender olarak yaklaşık 1-2 metre kalınlıkta kötü boylanmalı, polijenik çakıltaşı ara seviyelerine rastlanılmaktadır. Formasyon yoğun tektonik etkilerden dolayı ilksel konum ve özelliklerini yitirmiştir.

Formasyondan derlenen örneklerin, Jeo. Yük. Müh. Meltem KADINKIZ (MTA) tarafindan yapılan petrografik kayaç tanımlamaları sonucunda şu metamorfik kayaçlar saptanmıştır; serizit kuvarsşist, muskovit kuvarsşist, kloritoyid kuvarsşist, kuvarsit, kuvars arenit. Petrografik tanımlamalarda görülen mineral parajenezlerine 
göre formasyon yeşilşist metamorfizması koşulları altında metamorfizmaya uğramıştır.

Eldeş formasyonu çalışma alanının kuzeyinde Kara Tepe 1 km kuzeyinde Geç Prekambriyen yaşlı İhsaniye formasyonu üzerinde uyumsuz olarak gözlenmektedir. Formasyonun taban kesiminde yaygın olarak izlenen çakıltaşı seviyelerini oluşturan çakılların kökeni çalışma alanı dışında Gürsu ve Göncüoğlu [12] tarafından tanımlanan Devoniyen yaşlı Çalışlar formasyonu olarak düşünülmüştür.

Bölgeyi etkileyen Alpin tektonik hareketleri ile bu dokanak yer yer tektonik konumlu olarak gözlenmektedir. Formasyon üzerine Erken-Orta Triyas yaşlı Kıyır formasyonu uyumsuz olarak gelmektedir.

Formasyon çalışma alanı içinde tektonik etkiler nedeniyle kıvrımlı ve kırıklı bir yapı sunmaktadır. Eldeş formasyonunun çalışma alanı içinde yaklaşık 1000-1500 metre kalınlığa sahip olduğu tahmin edilmektedir.

MTA Orta Torosların Jeodinamik Evrimi projesi kapsamında, çalışma alanı dışında Ilgın (Konya) güneyinde, Eldeş formasyonu içinden derlenen örneklerde; paleontolog Dr. Burcu COŞKUN TUNABOYLU (MTA) tarafindan yapilan tayinlerde; Globivalvulina sp., Frondina sp., Staffella sp., Abadahella sp., Minajaponella sp., Tubiphytes sp. Hemigordius sp. ve Neoschwagerina sp. fosilleri saptanmış olup, formasyon yaşının Geç Permiyen olduğu belirlenmiştir. Formasyon tabanında gözlenen kalın çakıltaşı seviyeleri göz önüne alındığında formasyonun yaşı Permiyen olmalıdır. İnceleme alanında tabanda yer alan ve karasal kökenli olarak kabul edilen metaçakıltaşı seviyeleri yüksek enerjili bir ortamı karakterize etmekte, üst seviyelere doğru gözlenen kırıntılı birimler ve karbonatlar ise sı̆̆ denizden, şelf ortamına geçildiğini göstermektedir.

\subsubsection{Kıyır Formasyonu (Trk)}

İlk kez Özcan ve ark [8] tarafından adlandırılan Formasyon başlıca alacalı renkli şistler, metakumtaşı, metasilttaşı ve metaçakıltaşı birimlerinden oluşmaktadır. Birim, Konya civarında Özcan ve ark [7] tarafindan tanımlanan Ardıçlı formasyonu ile benzer özellikler gösterir. Formasyonun tip kesit yeri; çalışma alanı dışında Kıyır çayında (Kıyır Köyü) izlenmekte olup; çalışma alanı dışında Kayaboğaz Dere ve Paşadağ (S7) batısı formasyonun başvuru kesit yerleridir. Birim, başlıca kristalize kireçtaşı çakıl tanelerinden oluşan çakıltaşı seviyesi ile başlamaktadır. Çakıltaşları genellikle çok kötü boylanmış, az yuvarlaklaşmış, çoğunlukla mermer çakıllarından oluşmakta olup, çakı1 boyutları blok boyutuna (yaklaşık $50 \mathrm{~cm}$ ) ulaşmaktadır.

Çakıltaşları gri renkli, belirgin bir yönlenme gösteren şistler ve metasilttaşları ile ardalanmalı olarak gözlenmektedir. Çakıltaşı seviyeleri kalın katmanlı olarak yanal yönde belirgin olarak izlenmektedir. Bu metaçakıltaşları Metin ve ark. [13] tarafından Afyon metamorfitleri içinde Bayat metakonglomera üyesi olarak tanımlanmıştır.

Çakıltaşı sevileri üzerine gelen yeşil-bordo-kahve renkli şistler, belirgin şistozite ve yapraklanma göstermektedir ve egemen litoloji konumundadır. $\mathrm{Bu}$ alacalı seviyeler tüm Toros kuşağı boyunca Triyas yaşı birimler için ayırtman niteliğindedir. Şistler içinde açık krem-beyaz, yer yer koyu gri renkli, orta-kalın tabakalı kuvars arenit ve metasilttaşı seviyeleri ara katmanlar şeklinde izlenmektedir. İstif üst seviyelere doğru yeşil-gri renkli şistler ile ardalanan bej-sarımsı renkli kristalize kireçtaşı ara tabakaları ile sonlanmaktadır.

Formasyondan derlenen örneklerin, Jeo. Yük. Müh. Meltem KADINKIZ (MTA) tarafindan yapılan petrografik tanımlamaları ile; kuvars arenit, muskovit kuvarsşist, muskovit kloritoyid kuvarsşist, klorit muskovit kuvarsşist, meta kuvars arenit, kuvars mikaşist, mika kuvarsşist kayaçları saptanmıştır.

Kıyır formasyonu, Permiyen yaşlı Eldeş formasyonu üzerinde uyumsuz olarak bulunmaktadır. Formasyon üst seviyelerindeki şistkristalize kireçtaşı ardalanması ile Paşadağ üyesine geçiş gösterir. Kıyır formasyonu, bölgede gelişen 
Alpin tektoniği ile ilksel konumunu kaybetmiş olduğu için, gerçek kalınlığı belirlenememiştir. Ancak, arazi gözlemlerine dayanılarak formasyon kalınlığının yaklaşık olarak 300-500 m arasında olduğu söylenebilir. Formasyonun taban kesimlerindeki kırıntılı seviyelerden herhangi bir yaş bulgusu elde edilememiştir. Ancak, birimin tabanında taban çakıltaşı konumundaki litolojinin çoğunlukla Permiyen yaşlı Eldeş formasyonuna ait rekristalize kireçtaşlarından türediği ve bu nedenlede formasyonun yaşının Erken-Orta Triyas yaşında olabileceği düşünülmüştür. Formasyonun üst seviyelerinde Paşadağ üyesi ile olan geçişinden alınan örneklerden herhangi bir yaş elde edilememiştir.

Özcan ve ark. [8], çalışma alanı dışında AfyonEskişehir karayolunun 55. km'sindeki, Aykırıkçı Köyünün 4 km doğu kesimlerinde Gökçeyayla formasyonu ile olan dokanağındaki kristalize kireçtaşlarında saptadıkları Glomospira sinensis $\mathrm{HO}$, Glomospirella shengi $\mathrm{HO}$ ve Glomospira sp. fosilleri ile birimin yaşının Skitiyen-Erken Anisiyen olduğunu saptamışlardır.

Özcan ve ark. [8], formasyonun tabanında yer alan çakıltaşı seviyelerinin yakınsak alüvyon yelpazesi, orta seviyelerde gözlenen kırıntılı istiflerin menderesli nehir çökelleri, taşkın ovası ve kıyı ovası koşullarını, üst seviyelerde gözlenen şist ara tabakalı kristalize kireçtaşlarının ise gelgit arasıgelgit altı ve açık şelf ortam koşullarını gösterdiğini belirtmişlerdir.

Kiyır formasyonu Eren [16] tarafından tanımlanan Gökçeyurt Grubu içinde yer alan Aladağ formasyonu ile benzer özellikler gösterir. Özcan ve ark. [18] tarafından Konya-Ilgın civarında Ardıçlı formasyonu içinde tanımlanan Morbel Tepe ve Seyrantepe üyelerini içermektedir. Konya ve civarında yüzeyleyen Bahçecik formasyonu Hüseyinca [19] ile deneştirilebilir.

\subsubsection{Gökçeyayla formasyonu (TrJKrg)}

Çalışma alanının kuzeybatısında Gökçeyayla Köyü civarında yüzeyleyen, başlıca kristalize kireçtaşı, dolomitik kireçtaşı ve metasilttaşlarından oluşan birim, ilk kez Özcan ve ark [8] tarafindan
Gökçeyayla formasyonu olarak tanımlanmıstır. Bu çalışmada formasyon farklı litolojik ve yapısal özellikleri nedeni ile 2 üyeye ayrılarak incelenmiştir.

Formasyon çalışma alanındaki tektonik etkiler nedeniyle düzenli bir istif sunmamaktadır. Gökçeyayla formasyonu içinde ilk kez tarafımızdan tanımlanan Paşadağ üyesi başlıca kireçtaş1, kristalize kireçtaşı, şist ve metasilttaşı litolojilerinden oluşmakta olup, Paşadağ civarında yaklaşık K-G doğrultulu olarak izlenmektedir. Bu üye Paşadağ (S7) $1 \mathrm{~km}$ batısında Permiyen yaşlı Eldeş formasyonu tarafindan tektonik olarak üzerlenmektedir.

Gökçeyayla formasyonunun üst seviyesini oluşturan ve [20] tarafindan Orta-Üst Triyas yaşlı Karacaçal Tepe formasyonu olarak tanımlanan birim, başlica dolomit ve dolomitik kireçtaşlarından oluşmakta olup, tarafımızdan Karacaçal Tepe üyesi şeklinde tanımlanmıştır. Karacaçal Tepe üyesi Paşadağ civarında izlenememektedir. Çalışma alanının doğu kesimlerinde yaygın olarak izlenen, Karacaçal Tepe üyesi İhsaniye ve/veya Eldeş formasyonunu tektonik olarak üzerlemektedir.

Gökçeyayla formasyonu tabanda Erken-Orta Triyas yaşlı Kıyır formasyonu ile geçişli, çalışma alanında izlenemeyen üst dokanağı ise; [8]'ne göre Geç Kretase yaşlı Çöğürler karışığı ile geçişli bir dokanağa sahiptir. Gökçeyayla formasyonunun tamamı çalışma alanı içinde izlenemediğinden kalınlık vermek mümkün değildir. Ancak, çalışma alanı dışında [8], formasyon kalınlığının yaklaşık olarak 1000 metre olduğunu ifade etmişlerdir.

Özcan ve ark. [8] ve Göncüoğlu [17] formasyonun Orta Triyas-Geç Kretase yaş zaman aralığında çökeldiğini, belirli bir uyumsuzluk gözlenmediğini belirtmişlerdir.

Formasyon, Konya civarında Eren [16] tarafindan tanımlanan Lorasdağı formasyonu, Göğer ve Kıral [21] tarafindan tanımlanan "Lorasdağı kireçtaşı", Özcan ve ark. [7] tarafindan tanımlanan "Loras formasyonu" ile deneştirilebilir. 


\subsection{Paşadağ üyesi (TrJKrgp)}

Başlıca kirli sarı renkli kireçtaşı, kristalize kireçtaşı, şist, metasilttaşı ardalanmasından oluşan üye adını çalışma alanının güney kesimlerinde yer alan Paşadağ'dan alır. ilk kez Metin ve ark. [13] tarafından Paleozoyik yaşlı birimler içinde Paşadağ kireçtaşı üyesi şeklinde tanımlanan birim, tarafimızdan Orta Triyas-Geç Kretase yaşlı Gökçeyayla formasyonu içinde üye şeklinde tanımlanmıştır. Birim taban kesimlerinde şist ara tabakalı kristalize kireçtaşları ile başlar, sarımsıbej renkli kristalize kireçtaşları, yeşil-gri renkli şistler ve metasilttaşları ile ardalandıktan sonra, gri-beyaz renkli dolomitik rekristalize kireçtaşlarına geçiş gösterir. Kireçtaşları alt kesimlerde ince-orta tabakalı, üst seviyelere doğru orta-kalın tabakalı, yer yer kumlu kireçtaşı şeklinde izlenmektedir.

Üst seviyelerde gözlenen dolomitik kireçtaşları gri-beyaz renkli, orta-kalın tabakalı, yer yer metamorfizma nedeniyle masif görünümlüdür. Dolomitik kireçtaşları içinde yeşil-kahve renkli ince-orta tabakalı, kuvars arenit, kalkşist ve şist ara seviyeleri izlenmektedir.

Paşadağ üyesi çalışma alanında Paşadağ (S7) bölgesinde kuzey-güney uzanımlı olarak izlenmektedir. Formasyonun tip kesit yeri, Paşadağ ve çalışma alanı dışında yer alan Gökçeyayla Köyü civarındadır.

Paşadağ üyesi Erken-Orta Triyas yaşlı Kıyır formasyonu ile geçişli bir dokanağa sahiptir. Birimin üst seviyelerini, çalışma alanı dışında Gökçeyayla köyü civarında uyumlu olarak geldiği görülen Orta Triyas-Jura-Kretase yaşlı Karacaçal Tepe üyesi oluşturmaktadır.

Paşadağ (S7) $1 \mathrm{~km}$ doğusunda izlenen Paşadağ ekayı ile üzerlenen birim, çok kıvrımlı bir yapı sunmaktadır.

Arazi çalışmaları sırasında gözlemlenen kıvrımlı yapılar nedeniyle, formasyon kalınlığı hakkında kesin bir değerlendirme yapılamamıştır. Ancak, birimin kalınlığının 250-300 metre olabileceği düşünülmüştür. Özcan ve ark. [8] formasyonun taban kesimlerinde yer alan yeniden kristalleşmiş kireçtaşı ve metasilttaşı ardalanmasının 25 metre olduğunu belirtmektedir. Metin ve ark. [13] formasyon kalınlığının 250 metreye ulaştığını rapor etmişlerdir.

Çalışma alanında birimden alınan örneklerden herhangi bir yaş bulgusu elde edilememiştir. Ancak, Afyon-Eskişehir karayolunun 55. km'sindeki, Aykırıkçı Köyünün 4 km doğu kesimlerinde, Gökçeyayla formasyonunun çeşitli kesimlerinden Özcan ve ark. [8] tarafından alınan örneklerin mikroskobik yaş tayinlerinde tanımlanan; Involutina sp., Trochammina almptolansis Koehn-Zann, Endothyranella sp., Glomospirella densa (PANTIC), Turritella sp., Glomospirella sp., Glomospirella semiplana (KOCHANSKY), Glomospirella triphonensis Baud. Zann. ve Bozorgnia fosilleri ile Anisiyen yaşını elde etmişlerdir. Birimin üzerine geçişli olarak gelen Krarcaçal Tepe üyesinden elde edilen yaşlara göre birim Orta Triyas yaşlı olarak düşünülmüştür. Paşadağ üyesi, şelfin zaman zaman sı ̆g denizele dönüştüğü bir gel-git ortamında oluşmuş olmalıdır. Göncüoğlu [17], Paşadağ üyesinin sınırlı denizel sığlıklarda, sirkülasyonun sınırlı olduğu ortamlarda çökeldiğini belirtmiştir.

Bu çalışmada Gökçeyayla formasyonunun Paşadağ üyesi olarak tanıtılan birim, Hüseyinca [19] tarafından Ilgın (Konya) kuzeyinde tanımlanan Ertuğrul formasyonu ile deneştirilebilir.

\subsection{Karacaçal Tepe üyesi (TrJKrgk)}

İlk kez Karacaçal Tepe üyesi olarak tanımlanan birim başlıca dolomit, dolomitik kireçtaşı ve kristalize kireçtaşlarından oluşmaktadır. Özcan ve ark. [8] tarafından Orta Triyas-Kretase yaşlı Gökçeyayla formasyonun içinde ayırtlanmadan tanımlanan birim, Göğer ve Kıral [21] tarafindan Orta-Üst Triyas yaşlı Karacaçal Tepe formasyonu şeklinde tanımlanmıştır.

Birimin tip kesit yeri; çalışma alanı dışında Afyon ili, Bayat İlçesi yaklaşık 20 kilometre kuş uçuşu kuzeybatısında yer alan Gökçeyayla Köyü ve Emirdağı İlçesi civarındaki Karacaçal Tepe'dir. Tabanda dolomit, dolomitik kireçtaşı seviyeleri ile 
başlayan Karacaçal Tepe üyesi, üst seviyelere doğru rekristalize kireçtaşı seviyeleri ile devam etmektedir. Dolomitler açık gri-füme renkleri ile arazide çok belirgindir. Birim içinde yer yer koyu gri-siyah renkli, orta-kalın tabakalı dolomitik kireçtaşları görülmekte ve bu litolojiler içinde lamellibranş ve gastropod kavkıları çok net olarak izlenebilmektedir. Koyu gri-siyah renkli bu dolomitik seviyelerin üst kesimlerinde açık gri renkli oolitik kireçtaşı seviyeleri yaygındır. Açık gri renkli dolomitik seviyeler belirgin laminalanmalı ve intraformasyonal breşli olarak izlenmektedir.

Çalışma alanında çok az izlenen rekristalize kireçtaşları beyaz-gri renkli, taze yüzeyi beyaz renkli, orta- kalın tabakalanmalıdır.

Çalışma alanı dışında Özcan ve ark. [8] tarafından yapılan çalışmalarda Gökçeyayla formasyonu Orta Triyas'tan başlayarak Geç Kretase'ye kadar düzenli bir istif sunmaktadır. Karacaçal Tepe üyesi elde edilen yaşlar ve arazi gözlemlerine göre Paşadağ üyesi ile uyumlu bir dokanağa sahiptir. Karacaçal Tepe üyesi çalışma alanında İhsaniye formasyonu ve yer yer Eldeş formasyonunu tektonik dokanakla üzerlemektedir. Çalışma alanı içinde birimin üst dokanağı izlenememektedir.

Çalışma alanında Karacaçal Tepe üyesinin tamamı izlenmemektedir. Çalışma alanı dışında Özcan ve ark. [8] tarafindan tanımlanan Gökçeyayla formasyonun kalınlığı yaklaşık 1000 metre, Göğer ve Kıral [21], Karacaçal Tepe olarak tanımladığı formasyon için $572 \mathrm{~m}$ kalınlık vermiştir. Çalışma alanı dışında Afyonkarahisar-Sultandağı kuzeyinde "MTA Orta Torosların Jeodinamik Projesi" kapsamında yapılan çalışmalarda, formasyon içindeki koyu gri-siyah renkli dolomitik kireçtaşlarından alınan örneklerde Aulotortus sp. kalıpları ve lamellibranş kavkıları; Konya-Ilgın güneyinde formasyonun taban kesimlerinde bulunan kireçtaşlarından alınan örneklerde gözlenen Aulotortus sp., Nodosariidae ve lamellibranş kavkıları ile birimden Orta-Geç Triyas yaşları elde edilmiştir. Çalışma alanı dışında Özcan ve ark. [8] Karacaçal Tepe üyesi ile eşdeğer özellikteki kayaç topluluğundan aldığ1 örneklerden belirledikleri İnvolutina sinuosa pragsoides (Oberhauser), Involutina sp., Trocholina sp. ve Clomospira sp. fosillerine göre birimin taban kesimi için Geç Anisiyen-Geç Noriyen yaşını, Orbitoides sp., Lepidorbitoides sp., Siderolites sp., Semplorbitoides sp. ve Omphalacyclus sp. fosilleri ile formasyonun üst sınırından Geç Kretase yaşlarını elde ederek üyenin yaşının Orta Triyas-Geç Kretase yaşında olduğunu belirlemişlerdir. Çalışma alanı ve dışında birim içinde herhangi bir uyumsuzluk izlenmemiştir Karacaçal Tepe üyesi, Özcan ve ark. [8] ve Göncüoğlu [17]'na göre sinırlı şelf koşullarında çökelmiştir. Formasyon içinde gözlenen oolitik kireçtaşı seviyeleri sı̆̆ ve 1 lık ortam koşullarını yansıtmaktadır.

Karacaçal Tepe üyesi, Özcan ve ark. [7] tarafından Konya civarında tanımlanan Loras formasyonu, Eren [16] tarafindan tanımlanan Lorasdağ1 formasyonu ve birimin taban kesimi Hüseyinca [19] tarafindan Ilgın (Konya) kuzeyinde tanımlanan Kizılören formasyonu ile deneştirilebilir.

\subsection{2. Örtü Birimleri}

Prekambriyen-Kretase yaş aralığındaki birimler üzerine çökelen kayaç topluluğu bu çalışmada Örtü birimleri başlığı altında incelenmiştir. Tabanda Erken Miyosen yaşlı Beşsaray formasyonu ile başlayan istif üzerine, Erken Miyosen-Pliyosen yaşlı gölsel Akpınar formasyonu gelmektedir. Erken Miyosen-Pliyosen süresince bölgede faaliyet gösteren volkanizma ürünlerinden Erken MiyosenPliyosen yaşlı Seydiler ignimbiritleri gölsel çökeller ile yanal ve düşey geçişli olarak izlenmektedir. Pliyosen yaşlı Yapılıkale Tepe volkanitleri, çoğunlukla Seydiler ignimbiritleri üzerinde olmak üzere, Mesozoyik yaşlı birimler ve Akpınar formasyonu üzerinde izlenmektedir. Pliyosen yaşlı Erdemir formasyonu ve Kuvaterner yaşlı alüvyonlar tüm birimleri uyumsuz olarak örtmektedir.

\subsubsection{Beşsaray formasyonu $(\mathrm{Mb})$}

İlk kez Göktaş [22] tarafindan tanımlanan formasyon alüvyon yelpazesi çökellerinden çakıltaşı ve kumtaşı litolojilerinden oluşmaktadır. 
Formasyon çalışma alanı içinde Özburun Beldesi'nin (P12) $3 \mathrm{~km}$ batısında Ambar deresinde (P9) gözlenmektedir.

Beşsaray formasyonu, koyu sarı renkli, tane boyu 2-15 cm arasında değişen, yarı köşeli-yarı yuvarlak, çoğunlukla kötü çimentolanmış, gevşek yapılı olup, bu çalışmada Temel Birimler olarak tanımlanan formasyonların çakıllarından oluşmaktadır. Formasyon tamamiyla karasal kökenli malzemelerden oluştuğu için yaş verebilecek herhangi bir fosil içeriğine sahip değildir. Ancak, üzerine uyumlu olarak gelen Akpınar formasyonunun taban kesimlerinde oluşan kömürlerden Metin ve ark.[13] tarafindan alınan örneklerin polen analizlerinden Orta-Geç Miyosen yaşı almıştır. Buna göre formasyonun yaşı ErkenOrta Miyosen olmalidır.

Birim, temel birimler üzerine açısal uyumsuzlukla gelmekte olup, üzerine gelen Akpınar formasyonu ile düşey ve yanal yönde geçişlidir. Akpınar Köyü kuzeyinde Kartalkanat [23] tarafindan yapılan linyit sondajlarında da Beşsaray formasyonuna ait çakıllar saptanmıştır.

Akpınar formasyonunun tabanında sondajlarda gözlenen 13 metre kalınlığa sahip taban çakıltaşı seviyeleri, havza kenarlarında yaklaşık 60-70 metre kalınlığa ulaşmaktadır.

Formasyon tamamen karasal akarsu, alüvyon yelpazeleri, taşkın ovaları, örgülü ırmak yatakları, delta ve göl ortamında çökelmiştir [13].

$\mathrm{Bu}$ çalışmada Beşsaray formasyonu olarak tanitılan birim, Metin ve ark [13] tarafindan Yeniköy formasyonunun taban kesiminde tanımladıkları ve Neojen havzasının tabanı olarak öngördükleri konglomera üyesi ile deneştirilebilir.

\subsubsection{Akpınar formasyonu (MPla)}

Adını en iyi görüldüğü yer olan Akpınar Köy'ünden alan, Akpınar formasyonu başlica kireçtaşı, marn ve kiltaşı ardalanmasından oluşmaktadır. İlk kez Metin ve ark [13] tarafindan Yeniköy formasyonunun marn üyesi, Gebeciler formasyonunun Özburun marn üyesi ve Akpınar kireçtaşı üyesi olarak tanımlanan üyeler, Akpınar formasyonu adı altında incelenmiştir. Formasyon Göktaş [22] tarafından Cevizli formasyonu adı altında incelenmiştir.

Akpınar formasyonunun tip yeri Akpınar Köyü (K7), Değirmendere (L7) yamaçları ve Kazankaya Tepe (D8) KD'sudur. Akpınar formasyonunun alt kesimlerinde linyit oluşumları bulunmaktadır. İnceleme alanı içinde $30 \mathrm{~cm}$ civarında kalınlıklarda izlenen linyit oluşumlarının, Kartalkanat [23] tarafindan yapılan sondajlarda toplam $135 \mathrm{~cm}$ 'ye ulaştığı belirlenmiştir.

Akpınar formasyonunun oluşumu sırasında bölgede oluşan volkanik aktiviteler sebebi ile gölde oluşan birimler volkanik bileşence zenginleşmektedir. Marnlar; beyaz-bej renkli, ince-orta tabakalıdır. Kiltaşları; krem-bej renkli, kırılgan, yapraklanmalı özellik göstermektedir. Formasyonun taban kesimlerinde gözlenen marnlar ve ince tabakalı kiltaşı seviyeleri bol yaprak fosili ve gastropod kavkıları içermektedir. Kireçtaşı ve marn tabakaları arasında çok ince killi seviyeler bulunmaktadır.

Akpınar formasyonunu oluşturan kireçtaşları beyaz-krem renkli, ince-orta tabakalı, üst seviyelerde bulunan kireçtaşları lamelli ?, gastropod kavkılı ve silis yumrulu ve/veya silis ara tabakalı olarak izlenmektedir.

Beşsaray formasyonu üzerinde yanal ve düşey yönde uyumlu olan Akpınar formasyonu, yanal ve düşey yönde uyumlu olarak Seydiler ignimbiritlerine geçer. Formasyon içinde gözlenen silis yumruları bölgede gelişen volkanizmanın zaman zaman gölsel ortama ulaştığını göstermektedir.

Kalınlığı gölün sığ kesimlerinde 70 metre Göktaş [22] olarak ifade edilen Akpınar formasyonunun, Bayat ilçesi Derbent köyü güneyinde Kartalkanat [23] tarafindan yapılan linyit arama sondajlarında, 270 metre kalınlığa sahip olduğu saptanmıştır.

İnceleme alanında Akpınar Köyü doğusunda yüzeyleyen formasyonun üst seviyelerinden alınan yıkama örneklerinde, Dr. Gönül ÇULHA (MTA) 
tarafindan saptanan Heterocypris salina salina (Brady), Candona sp., Candona (Caspiolla) sp., Candona cf. candida (Müller), Candona cf. neclecta Sars, Candona parallela pannonica Zalanyi, Candona cf. decimai Freels ve Ilyocypris bradyi Sars fosilleri ile Geç Miyosen-?Pliyosen yaşı elde edilmiştir. Alınan örneklerin formasyonun üst seviyelerinden alınmış olması nedeniyle formasyon yaşının Erken Miyosen?Pliyosen olmalıdır. Dr. Gönül ÇULHA (MTA) tarafindan tanımlanan ostrakodlara göre formasyon tatlısu ortamında çökelmiştir.

\subsubsection{Seydiler ignimbiritleri (MPIs)}

Afyon kuzeyinde çalışan Aydar ve ark. [24] tarafindan tanımlanan Seydiler ignimbiritleri, Göktaş [22] tarafindan Köroğlu volkanitleri şeklinde tanımlanmıştır. Birim çoğunlukla ignimbiritlerden ve tüflerden oluşmaktadır.

Aydar ve ark. [24] birim içinde gözlemledikleri işlenmiş tüfler nedeni ile birimin iki evrede oluştuğunu belirterek, birimi Alt Seydiler ignimbiriti ve Üst Seydiler ignimbiriti şeklinde incelemişlerdir. Birim genellikle pekişmemiş veya zayıf pekişmiş olarak izlenmesine rağmen, pekişmiş bölümler kaldera çevresini oluşturan Alt Seydiler ignimbiritinin üst seviyelerinde gözlemlenmektedir. Alt Seydiler ignimbiritinde soğuma sütunları iyi gelişmiştir. Alt Seydiler ignimbiritinin pekişmemiş kesimleri beyaz ve gri renklerde izlenirken, pekişmiş bölümler ise sarı ve kırmızımsı tonlarda görülmektedir [24].

Birimden alınan örneklerin Schmidt [25]'e göre yapılan granülometrik sinıflamasına göre formasyon içinde vitrik tüf, kristal tüf ve lapilli tüf kaya türleri saptanmıştır.

Vitrik tüfler içinde volkanik camlar yoğun olarak gözlenmekte olup, bunlar pümis ve volkan camı kıymıkları şeklindedir. Volkan camları killeşmiştir. Birim içinde az miktarda gözlenen kristaller kuvars, polisentetik ikizlenme ve zonlanma gösteren feldispat ve kloritleşmiş biyotit şeklindedir.

Kristal tüfler kuvars ve feldispat minerallerinden oluşmaktadır. Kuvars ve feldispat mineralleri köşeli-az köşeli ve çatlaklı olup, feldispatlar polisentetik ikizlenme gösteren plajiyoklaz şeklindedir. Az oranda rastlanılan volkanik camlar silisleşmiş veya killeşmişlerdir. Kayaç içerisinde çok az oranda volkanik kayaç parçası ve tüf parçaları saptanmıştır. Lapilli tüfler çoğunlukla volkanik kayaç parçacıkları fazla miktarda izlenmekte olup, az oranda volkan camı ve kristal olarak kuvars, feldispat ve biyotit içermektedir. Birim Akpınar formasyonu ile yanal ve düşey geçişli bir dokanağa sahiptir. Birimin üzerine ise Yapılıkale Tepe volkanitleri gelmektedir. İnceleme alanında temel birimler üzerinde de uyumsuz dokanağa sahiptir.

Alt Seydiler ignimbiriti kaldera yakın çevresinde 250 metre kalınlığa ulaşırken, uzak bölümlerde kalınlığı 70 metreye kadar inmektedir. Üst Seydiler ignimbiriti kaldera çevresinde $200 \mathrm{~m}$ kalınlığa ulaşmaktadır [24]. İnceleme alanı dışında Akpınar formasyonunu üzerleyen Seydiler ignimbiritlerinin yaşı Anderson'a göre 18,6 + 0,5 my'lık 40Ar/39Ar yaşı, bağıl olarak çökel istiflerin üst sınırını belirlemektedir [26]. Yalçın [27], çalışma alanı dışında pümisler ve bazaltik lavlarda yapmış olduğu radyometrik (K/Ar) analizlerde, sırasıyla 19 ve 9 my yaş değerlerini elde etmiştir. Elde edilen bu yaşlara ve arazi çalışmaları sırasında gözlenen dokanak ilişkilerine göre formasyon Erken Miyosen-Pliyosen yaş aralığında oluşmuş olmalıdır.

Seydiler ignimbiritleri Metin ve ark.[13] tarafindan çalışma alanında tanımlanan Seydiler tüf ve aglomeraları ve Göktaş [22] tarafindan tanımlanan Köroğlu volkanitleri ile deneştirilebilir.

\subsubsection{Yapılıkale Tepe volkanitleri (Ply)}

Başlıca alkali bazalt, bazalt, trakit ve andezitlerden oluşan birim adını en yaygın yüzeylemelerinin bulunduğu Güney köyü (N19) kuzeydoğusundaki Yapılıkale Tepe'den (M21) almaktadır. Yapılıkale Tepe volkanitleri çalışma alanı dışında Metin ve ark.[ [13] tarafindan andezit, trakit ve bazaltlar ayrı ayrı tanımlanarak haritalanmıştır. Yapılıkale Tepe volkanitleri içinde izlenen bazaltlar siyah, koyu gri renkli, Fe'ce zengin kesimlerinde kızılımsı 
rengiyle ayırt edilmektedir. Birim sağlamdayanımlı olup, gaz boşlukları içermektedir. Bazaltlar İnpınar köyü (J3) civarında yastık yapılı ve gaz boşluklu olarak yaygın şekilde izlenmektedir. Andezitler gri-kül renkli, mineralleri iri ve belirgin olarak izlenmektedir Birim çalışma alanında Erken Miyosen-?Pliyosen yaşlı Akpınar formasyonunu ve Erken MiyosenPliyosen yaşlı Seydiler ignimbiritlerini üzerlemektedir. İnceleme alanı içinde birim üzerine gelen herhangi bir birim izlenmemiştir. Arazi gözlemlerinde elde edilen verilere göre birimin yaşı Pliyosen'dir.

\subsubsection{Erdemir formasyonu (Ple)}

Metin ve ark. [13] tarafindan Gebeciler formasyonunun üst seviyeleri içinde Erdemir Konglomera üyesi tanımı yapılmış olup, bu çalışmada tanımlanan düzey Erdemir formasyonu olarak tanıtılmıştır.

Erdemir formasyonu başlıca çakıl, kum ve yer yer killerden oluşmaktadır. Birim içerisindeki çakıltaşı seviyeleri gri-boz renkli, kalın tabakalanmalı, az pekişmiş, polijenik özelliklidir.

İnceleme sahasında Taşlıdere köyü (P20) güneybatı kesimlerinde açılan kum ocaklarında izlenebilen birim, sarı-kırmızımsı renkli, pekişmemiş - çimentolanmamış kumlardan oluşmaktadır. Formasyon içindeki killi seviyelerde yaklaşık 1 metre kalınlığa ulaşan karbonat çimentolu çakıltaşı seviyeleri bulunmaktadır.

İnceleme alanı dışında, kalınlığı 40-50 metre'ye ulaşan Erdemir formasyonunun inceleme alanındaki kalınlığı 2-30 metre arasında değişmektedir. Erdemir formasyonu kendisinden yaşlı tüm birimleri açısal uyumsuzlukla üzerlemektedir. Özburun beldesi (P12) GB'sında yüzeyleyen Erken Miyosen-?Pliyosen yaşlı Akpınar formasyonu üzerinde uyumsuz olarak izlenmesi ve ayrıca formasyon içinde gözlenen tüf, andezit ve bazalt çakıllarından dolayı formasyon yaşının Pliyosen olduğu düşünülmektedir. Formasyon akarsu, alüvyal yelpaze ve yer yer lagüner ortam koşullarında çökelmiş olmalıdır. Eren [16] tarafından Ilgın
(Konya) civarında tanımlanan Topraklı konglomerası ile deneştirilebilir.

\subsubsection{Alüvyon (Qal)}

İnceleme alanı içinde akarsu çökelleri şeklinde gözlemlenen birim pekişmemiş çakıl, kum ve siltten oluşmaktadır.

\subsection{Metamorfizma}

İnceleme alanı içinde otokton olarak izlenen İhsaniye formasyonu Özcan ve ark.'na göre Triyas öncesi metamorfizmaya uğramıştır. Metamorfizmanın $450-500^{\circ} \mathrm{C}$ sicaklık ile $6-8 \mathrm{~kb}$ basınç koşullarında olduğu belirtmiştir [8]. Ayrıca Paleosen'nde gerçekleşen metamorfizmanın, mineral parajenezine göre çok düşük dereceli olduğu ifade edilmiştir.

Candan ve Çetinkaplan [11], Mesozoyik yaşlı formasyonlardan elde ettikleri karfolit minerallerine göre metamorfizmanın $6-9 \mathrm{~kb}$ ve $350^{\circ} \mathrm{C}$ altında gerçekleştiğini belirtmişlerdir. Buna göre çalışma alanının kuzey kesimlerinde düşük dereceli bir yeşilşist metamorfizmasından söz edilebilir.

İnceleme alanından derlenen örneklerin petrografik tanımlamalarında muskovit, klorit, kuvars mineral toplulukları, birimlerin yeşilşist fasiyesinde metamorfizma geçirdiklerini göstermektedir.

\subsection{Yapısal Jeoloji}

Ketin [28]Toridler, Şengör ve Y1lmaz [3] Anatolid-Torid Platformu, Okay [5] ve Okay ve Tüysüz [4] Afyon Zonu, Göncüoğlu ve ark. [30] Afyon-Bolkar Dağ Zonu şeklinde tanımlanan bölge Okay [31] tarafından Kütahya-Bolkardağ Kuşağı şeklinde tanımlanmış olup; Göncüoğlu [17], çalışma bölgesinin Kadomiyen, Varisken ve Alpin dönemi orojenezlerini geçirdiğini belirtmiştir. Yazar ayrıca Kütahya-Bolkardağ Kuşağının, İzmir-Ankara okyanusunun kapanması ve Torid-Anatolid kıtası kuzey kenarının Sakarya kıtası ile çarpışması sonucu naplı/dilimli bir kuşak şeklinde geliştiğini ve bu kuşak içinde Bornova Filiş Zonu, Tavşanlı Zonu, Afyon Zonu, Likya 
Napları, Kiklat Naplarının bulunduğunu belirtmektedir.

İnceleme alanı, Anotolid-Torid Platformu'nun kuzey kenarında yer alan Afyon Zonu üzerine, DB doğrultulu olarak naplanan Tavşanlı Zonu'nu güneyinde yer alır. Bu iki zonun K-KD'sunda yer alan Sakarya Zonu İzmir-Ankara Süturu olarak tanımlanan bir bindirme ile Tavşanlı Zonu üzerine naplanır. Çalışma alanının Doğu ve Batı kesimlerinde geniş yayılım sunan Geç Prekambriyen-Kretase yaş aralığındaki formasyonlarda yapılan doğrultu ve eğim ölçümlerine göre Temel Birimler K30B ve K10D arasında yoğunlaşan bir doğrultuya sahip oldukları saptanmıştır (Şekil 5).

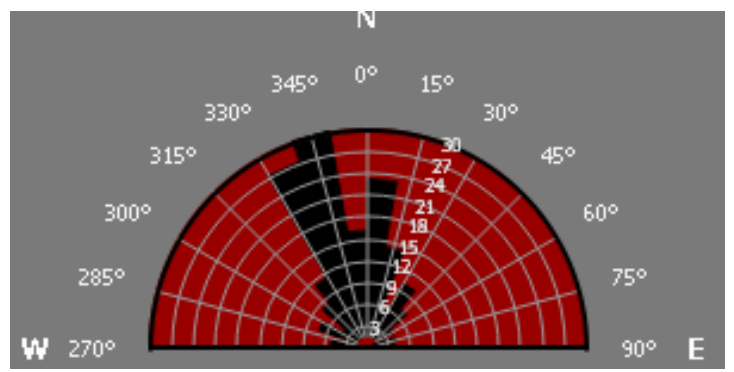

Şekil 5. Temel birimlerde ölçülen tabaka doğrultularına ait gül diyagramı.

Neojen yaşlı örtü birimlerinde yapılan tabaka doğrultu ve eğim ölçümlerinin değerlendirilmesi sonucunda, Neojen yaşlı birimlerin değişik yönlerde doğrultuya sahip oldukları saptanmasına rağmen, tabaka doğrultularının K60B ve K50D arasında geniş bir dağılım gözlenmiştir (Şekil 6).

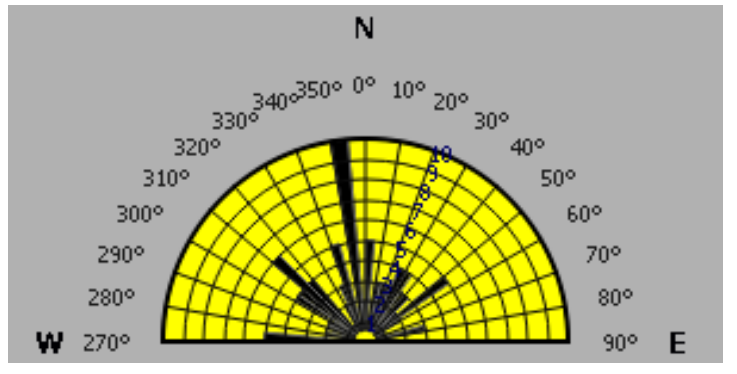

Şekil 6. Örtü birimlerinde ölçülen tabaka doğrultularına ait gül diyagramı.
Yapılan gül diyagramları ile çalıșma alanının Neojen öncesi KD-GB doğrultulu olarak sıkıştığ1 ve yaklaşık olarak KB-GD eksen uzanımlı antiklinal ve senklinallerin oluştuğu gözlenmiştir.

Örtü birimlerinde yapılan gül diyagramı ile Neojen yaşlı birimlerde düzenli bir yapısal unsur izlenememesine rağmen, tabaka doğrultularının KB-GD olduğu görülmüştür. Ancak, çalışma alanında oluşan kıvrımlı yapıların Miyosen sonrası gelişen tektonizmanın varlığını gösterdiği, çalışma alanı içinde ve dişında yapılan incelemelerde genişlemeli tektonik rejime uygun düşey yönlü normal fayların geliştiği, bu fay doğrultularının ise Afyon-Akşehir ve Bolvadin Grabeni'ne uygun olarak geliştiği gözlenmiştir.

\subsection{Jeolojik Tarihçe}

Ketin [28] tarafindan Pontitler, Anatolid-Torid ve Arap Platformları şeklinde tanımlanan tektonik birliklerin kaynaşması Oligo-Miyosen'e kadar devam etmiştir. Okay [31], Anatolid-Torid platformu içinde saptanan karfolit mineralinin varlığı ile Candan tarafından, Afyon Zonu'nun bölgesel bir yüksek basınç/düşük sıcaklık (YB/DS) metamorfizmasına sahip olduğu kabul edilmiştir [11].

Çoğu araştırıcı Anatolid-Torid birimlerinin Gondwana ile ilişkili olduğunu belirtmektedir [32- 34].

Afyon Zonu Prekambriyen-Kretase yaş aralığında, yeşilşist metamorfizmasına uğramış, taban kesimlerinde metasedimanter kırıntılı istif ve üzerine uyumsuz olarak gelen platform tipi karbonatlardan oluşmuştur.

Geç Prekambriyen yaşlı İhsaniye formasyonu Gondwana kıtasının kenar kesiminde oluşmuştur. İhsaniye formasyonu "çarpışma sonrası" tipte felsik magmatik kayalarla kesilmiştir. Gürsu ve Göncüoğlu [12] tarafindan felsik kayalardan elde edilen zirkon yaşları ile İhsaniye formasyonun Geç Prekambriyen yaşlı olduğu kabul edilmiştir. Gürsu ve Göncüoğlu, [35, 36] ile Akal ve ark. [37], Gondwana kuzey kenarında gelişen bu magmanın güneye dalan bir okyanusal kabuktan 
kaynaklandığını ileri sürmektedirler. AnatolidTorid platformunun temelini oluşturan bu birimlerin Erken Kambriyen'de metamorfizma geçirdiği çeşitli araştırıcılar tarafından ifade edilmiştir $[35,38]$.

İnceleme alanında Permiyen yaşlı Eldeş formasyonu uyumsuz olarak temel kayaçlar üzerinde çökelmiştir. $\mathrm{Bu}$ durum bölgenin Permiyen öncesi çok büyük aşınmalara uğradığını göstermektedir. Permiyen'e kadar olan bu karasal koşullar sonrası denizaltı yelpaze çökelleri ve akarsu çökelleri şeklinde çökelen kaba çakıltaşı seviyeleri ile birlikte ortam denizel ortam koşullarına dönmüştür.

Permiyen sonrası olası yersel yükselmelere bağlı olarak Permiyen yaşlı Eldeş formasyonu aşınmalara uğramış ve Erken-Orta Triyas yaşlı Kıyır formasyonu uyumsuz olarak karasal ve geçiş ortamlarını yansıtan litolojilerle çökelmeye başlamıştır. Orta Triyas ve sonrasında ise bölge denizel konuma gelmiş ve ortam duraylaşarak platform çökellerinin oluşmasına olanak sağlamıştır.

Kretase'ye kadar devam eden duraylı ortam, NeoTetis okyanusunun kuzey kolunun kapanmasina bağlı olarak, istiflerin naplanarak Kretase yaşlı birimler üzerine gelmesi sırasında; çalışma alanı Alpin tektonik hareketlerine uğramış ve bu tektonik hareketlere uygun olarak kendi içinde kıvrımlanmış ve ekaylanmıştır.

İnceleme alanı ve batı kesiminde sicak su kaynaklarının varlığı, çalışma alanında civarında gözlenen volkanik birimler bölgedeki kitasal kabuğun kalın olmadığını göstermektedir.

Akal ve ark. [37], Gondwana'nın kuzey kenarında bir yay ardı rift ortamının gelişerek, Neo-Tetis Okyanusu'nun kuzey kolunun bu riftleşmeyle bağlantılı olarak açıldığını, karasal kökenli çakıltaşları ile yanal giriklik sunan asidik volkanizmanın geliştiğini belirtmiştir. Geç Skitiyen-Erken Anisiyen süresince bölgeye denizin kısmen ulaştığını ve kalın karasal çakıltaşlarının ince kireçtaşı bantları ve kıyıdenizaltı yelpazeleri şeklindeki çakıltaşı kanal dolguları içeren, sı̆̆ denizel çamurtaşları tarafından üzerlendiğini ifade etmektedir.

Torid-Anatolid Platformunun büyük bölümünde Orta Triyas (Anisiyen)-Geç Jura-Erken Kretase sırasında sırası ile sınırlı platform, açık platform ve nihayet yamaç koşulları egemen olmuştur. Farklı tektonik dilimlerde, çökelme ortamına ilişkin yanal fasiyes geçişleri ve bunların zamanı değişiklikler göstermekle birlikte, derinleşme genel hatları ile güneyden kuzeye doğru artmaktadır [17]. NeoTetis okyanusunun kuzey kolunun Kretase'de kapanmaya başlaması ile birlikte, Anodolid-Torid Kuşağı'nda bulunan birimler kuzeyden güneye doğru naplanarak bir yığışım kompleksi oluşturmuşlardır [1]. Yığışım prizması içinde kalan bu birimler gömülme derinliği ve konumlarına bağlı olarak metamorfizma geçirmişlerdir. Farklı metamorfizma yaşı ve derecesi gösteren bu birimler; birçok araştırıcı tarafından kabul edilmiş ve incelenmiştir.

İnceleme alanı içinde Afyon Zonu ile diğer zonlara ait birimlerin dokanağı izlenememiştir. Ancak, çalışma alanının kuzeyinde, Tavşanlı Zonu'na ait birimler Afyon Zonu birimleri üzerine tektonik olarak gelmektedir [39]. Yaklaşık KD-GB yönlü olarak gelişen tektonik hareketler, çalışma alanının kuzeyinde gözlenen KB-GD doğrultulu yapısal unsurlar ile örtüşmektedir. Ancak, çalışma alanının güneyinde izlenen yapısal unsurlar K-B doğrultulara sahip oldukları izlenmektedir. $\mathrm{Bu}$ durum çalışma alanını etkilen kuvvetin saat yönünde rotasyonal bir dönme yaptığını göstermektedir.

İnceleme alanının kuzeybatı kesimlerinde Han (Eskişehir) ilçesi civarında Özcan ve ark. [8] tarafından tanımlanan metamorfizma geçirmemiş Üst Paleosen-Eosen yaşlı çökel kayaların varlığı, Afyon zonu birimlerinin metamorfizma yaşının Erken Paleosen (60-65 My) olduğu sonucunu vermektedir.

\section{SONUÇLAR}

$\mathrm{Bu}$ çalışma ile çalışma bölgesinde 10 litostratigrafik birim tanımlanarak, çalışma 
alanının genelleştirilmiş stratigrafik kesiti hazırlanmıştır. Daha önceki çalışmacılar tarafından Afyon Metamorfitleri, İhsaniye Metamorfik Karmaşı̆̆ı, Afyon Temel Kompleksi ve Alt Topluluk (Pan Afrikan Temel) adlarıyla tanımlanan birimler, bu çalışmada İhsaniye formasyonu olarak tanımlanmıştır. İhsaniye formasyonu çalışma alanında yüzeyleyen en yaşlı birimdir. İhsaniye formasyonu üzerine transgresif olarak gelen çoğunlukla kuvarsit kökenli olan metaçakıltaşlarının Permiyen yaşlı Eldeş formasyonuna ait olduğu, çoğunlukla kristalize kireçtaşı çakıllarından oluşan birimin ise ErkenOrta Triyas yaşlı Kıyır formasyonunun taban çakıltaşı seviyeleri olduğu belirlenmiştir.

Eldeş formasyonunun taban kesimini oluşturan çakıltaşlarının İhsaniye formasyonu ve/veya çalışma alanı içinde izlenmeyen Devoniyen yaşlı Çalışlar formasyonundan türediği, Kıyır formasyonunun taban kesimlerinde izlenen çakıltaşı seviyelerinin ise Permiyen yaşlı Eldeş formasyonu içinde izlenen rekristalize kireçtaşlarından türediği sonucuna varılmıştır.

İnceleme alanında Geç Prekambriyen yaşlı İhsaniye ve Permiyen yaşlı Eldeş formasyonlarından derlenen örneklerin petrografik tanımlamaları ile yeşilşist fasiyesi özelliklerine sahip olduğu doğrulanmıştır.

Özcan ve ark. [8] tarafindan Gökçeyayla formasyonu olarak tanımlanan birim bu çalışmada farklı ardalanım sunması nedeniyle Paşadağı üyesi ve Karacaçal Tepe üyesi şeklinde 2 üyeye ayrılarak haritalanmıştır.

İnceleme alanının yüksek kesimlerinde yüzeyleyen volkanik birimler Yapılıkale volkanitleri olarak tanımlanmış ve adlandırılmıştır. Bölgede etkinlik gösteren volkanik birimlerin temel birimleri keserek yüzeye çıktığı, Miyosen yaşlı gölsel birimler ile yanal ve düşey ilişkili olduğu, volkanizmanın Pliyosen'e kadar devam ettiği saptanmıştır.

Afyon-Bolkar Kuşağı olarak tanımlanan bölgedeki, Prekambriyen - Kretase yaşlı birimlerin yeşil şist metamorfizmasına uğradıkları ve bu birimlerin [6] tarafından tanımlanan Geyikdağ Birliği ile benzer litolojik özellikler gösterdiği görülmüştür.Afyon Zonu olarak tanımlanan çalışma alanı ve civarında yüzeyleyen, Prekambriyen-Kretase yaş aralığında çökelmiş yeşilşist metamorfizması sunan stratigrafik birimlerin, Torid-Anatolid Platformun'da yüzeyleyen diğer stratigrafik istifler ile deneştirilmesi gerekmektedir.

\section{KAYNAKLAR}

1. Candan, O., Oberhansl1, R., Dora O.Ö., Çetinkaplan, M., Koralay, E., Rimmele, G., Chen, F. ve Akal, C., 2011. Menderes Masifinin Pan-Afrikan Temel ve PaleozoyikErken Tersiyer Örtü Serilerinin Polimetamorfik Evrimi. MTA Dergisi, 142, 123-165, Ankara

2. Özgül, N., 1971. Orta Torosların Kuzey Kesiminin Yapısal Gelişiminde Blok Hareketlerinin Önemi: Türkiye Jeol. Kur. Bült. 14,75-87.

3. Şengör, A.M.C. ve Yılmaz, Y., 1981. Tethyan Evolution of Turkey: A Plate Tectonic Approach, Tectonophysics, 75, 81-241.

4. Okay A.I. ve Tüysüz, O., 1999. Tethyan sutures of northern Turkey. In "The Mediterranean Basins: Tertiary Extension within the Alpine Orogen" (eds. B. Durand, L. Jolivet, F. Horváth and M. Seranne), Geological Society, London, Special Publication 156, 475-515.

5. Okay, A.I., 1984. Distribution and Characteristics of the North-West Turkish. Blueschists. Geological Society, London, Special Publications, v. 17; p. 455-466.

6. Özgül, N., 1976. Torosların Bazı Temel Jeoloji Özellikleri. JMO Bülteni, Ankara, 19, 65-78.

7. Özcan, A., Göncüoğlu, M.C., Turhan, N., Uysal, S., Şentürk, K. ve Işık, A., 1988. Late Paleozoic evolution of the Kütahya-Bolkardağ Belt, METU Journal of Pure and Applied Sciences , 21, 1/3, 211-220.

8. Özcan, A., Göncüoğlu, M.C., Turhan, N., $1989 . \quad$ Kütahya-Çifteler-Bayat-İhsaniye Yöresinin Temel Jeolojisi. MTA Rapor No:8974, Ankara, (yayımlanmamış). 
9. Tolluoğlu, A.Ü., Erkan, Y., Sümer, E.Ö., Boyacı, M.N. ve Yavaş (Betaş), F., 1997. Afyon Metasedimanter Grubunun Mesozoyik Öncesi Metamorfîk Evrimi, Türkiye Jeoloji Bülteni, Cilt 40, Sayı 1, s1-17, Ankara.

10. Göncüoğlu, M.C., 2007. Kütahya-Bolkardağ Kuşağının Jeolojisi. Menderes Masifi Kollokyumu. Proceedings-Bildiriler Kitab1, s:39-43.

11. Candan, O. ve Çetinkaplan, M., 2005. Bayatİscehisar (Afyon) Çevresindeki Mesozoik Yaşlı Kayaların Alpin Yüksek Basınç/Düşük Sicaklık Metamorfizması ve Batı Anadolu'daki Tektonik Ünitelerin Evrimiyle Olan İlişkisi. Türkiye Bilimsel ve Teknolojik Araştırma Kurumu (TÜBİTAK) Projesi No:101Y022.

12. Gürsu, S. ve Göncüoğlu, M.C., 2008. Petrogenesis and geodynamic evolution of the Late Neoproterozoic Post-Collisional Felsic Magmatism in NE Afyon Area, Western Central Turkey. In: The Boundaries of the West African craton. In:ENNIH, N. \& LIE' GEOIS, J.-P. (eds) The Boundaries of the West African Craton. Geological Society, London, Special Publications, 297, 409-431.

13. Metin, S., Genç, Ş., Bulut, V., 1987. Afyon ve Dolayının Jeolojisi. MTA Rapor No: 8103, Ankara, (yayımlanmamış).

14. Candan, O., Çetinkaplan, M., Oberhanslı, R., Rimmele, G., 2002. Afyon Zonu'nun Triyas Metasedimentleri İçerisinde Alpin Yaşlı Düşük Dereceli, Yüksek Basınç/Düşük Sicaklık Metamorfizması İle Bağlantılı Fe-Mg Karfolit Oluşumları. 55. Jeoloji Kurultayı Bildiri Özleri, s:46-49.

15. Gürsu, S., 2002. İç Batı Anadolu (Afyon GB'sı) Bölgesinde Yüzeylenen Paleozoyik Öncesi Magmatik Kayaçların Jeolojisi ve Petrojenezi. H.Ü. Fen Bilimleri Enstitüsü, Doktora Tezi. 204, Ankara, (yayımlanmamış).

16. Eren, Y., 1993. Konya Kuzeybatisında Bozdağlar Masifinin Otokton Ve Örtü Birimlerinin Stratigrafisi. Türkiye Jeoloji Bülteni, Cilt 36, s.7-23, Ankara.

17. Göncüoğlu, M.C., 2011. Kütahya-Bolkar Kuşağı'nın Jeolojisi. MTA Dergisi, 142, 227 282, Ankara,.

18. Özcan, A., Göncüoğlu, M.C., Turhan, N., Uysal, Ş., Şentürk, K. ve Işık, A., 1990.
Konya-Kadınhanı -Ilgın Dolayının Temel Jeolojisi. MTA Genel Müdürlüğü Jeoloji Etütleri dairesi. Rap. No. 9535, Ankara, (yayımlanmamış).

19. Hüseyinca, M.Y., 2005. Ilgın (Konya) Kuzeyinin Stratigrafisi ve Yapısal Özellikleri. S.Ü. Fen Bil. Enst. Yük. Lisans Tezi. 97s, Konya, (yayımlanmamış).

20. Uman, Ö., ve Yergök, F.A., 1979. Emirdağ (Afyon) Dolayının Jeolojisi. MTA Rapor No: 6604, Ankara, (yayımlanmamış)

21. Göğer, E. ve Kıral, K., 1969. Kızılören Dolayının Jeolojisi, MTA Rapor No: 5204, Ankara, (yayınlanmamış).

22. Göktaş, F., 2010. Kırka-Seyitgazi (ESKİŞEHİR) Havzası ve Çevresindeki Neojen Tortullaşması ile Volkanizmanın Jeolojik Etüdü. MTA Derleme No:11306, Ankara, (yayınlanmamış).

23. Kartalkanat, A., 1992. Afyon-Bayat (ÖİR-653) ve Sincanlı (ÖİR-21499 Bor Tuzu Ruhsat Sahalarının Jeolojik Değerlendirme ve Öneri Raporu. MTA EHM Dairesi. Ar. No:2438, Ankara, (yayınlanmamış).

24. Aydar, E., Bayhan, H. and Gourgaud, A., Koroglu 1998. Caldera, Mid-West Anatolia, Turkey:Volcanological and Magmatological Evolution. Journal of Volcanology and Geothermal Research., 85, 83-98p,

25. Schmidt, R., 1981. Descriptive Nomenclature and Classification of Pyroclastic Deposits and Fragments: Recommendations of the IUGS Subcommision on the Systematics of Igneous rocks, Geology, 9, 41-3,

26. Anderson, D., 1997. The Relationship Between Magmatism and Borate Mineralisation in Western Turkey; PhD Thesis, University of Leicester, $138 \mathrm{p}$.

27. Yalçın, H., 1988. Kırka (Eskişehir) Yöresi Volkanosedimanter Oluşumlarının Mineralojik - Petrografik ve Jeokimyasal İncelenmesi. Doktora Tezi, Hacettepe Üniversitesi, Fen Bilimleri Enstitüsü, 209s., Ankara, (Yayımlanmamış).

28. Ketin, İ., 1966, Ketin, İ, Anadolunun Tektonik Birlikleri, MTA.Enstitüsü Dergisi, 66, s:20-34,

29. Robertson, A.H.F., Parlak, O. and Ustaömer, T., 2012. Overview of the Palaeozoic-Neogene Evolution of Neotethys in the Eastern 
Mediterranean Region (Southern Turkey, Cyprus, Syria), Petroleum Geoscience,Vol. 18, 2012, Pp. 381-404.

30. Göncüoğlu, M.C.,Dirik, K.; Erler A., Yalınız, K., Özgül, L. ve Çemen İ., 1997. Tuz Gölü Havzası Batı Kesiminin Temel Jeolojik Sorunları: Türkiye Petrolleri Anonim Ortaklığı Rapor no: 3753, 114 s.

31. Okay, A.İ., 2008. Geology of Turkey: A synopsis. Anschnitt, 21, 19-42.

32. Göncüoğlu, M.C., Turhan, N. ve Tekin, K., 2003. Evidence for the Triassic Rifting and Opening of the Neotethyan izmir-Ankara Ocean, Northern Edge of theTauride-Anatolide Platform, Turkey Bulletin Geological Society Italy, Special Volume 2,203-212.

33. Okay, A.İ., Satır, I. and Siebel, W. 2006. PreAlpide Palaeozoic and Mesozoic orogenic events in Turkey. In: Gee, D.G. \& Stepherson, R.A. (eds) European Lithosphere Dynamics. Geological Society, London, Memoirs, 32, 355-388.

34. Robertson, A.H.F. and Ustaömer, T., 2009. Formation of the Upper Palaeozoic Konya Complex And Comparable Units İn Southern Turkey Subduction-Accretion Processes: Implications for the Tectonic Development Of Tethys İn The Eastern Mediterranean Region. Tectonophysics, 473, 113-148,

35. Gürsu, S. ve Göncüoğlu, M.C., 2005. Early Cambrian Back-Arc Volcanism in the Western Taurides, Turkey: İmplications for Rifting Along The Northern Gondwanan Margin. Geological Magazinee. 142, 617-631.

36. Gürsu, S. ve Göncüoğlu, M.C., 2006. KütahyaBolkardağ Kuşağında (Afyon-İhsaniye) Yeralan Pan-Afrikan Yaşlı Felsik Magmatizmanın Petrojenezi. 59. Jeoloji Kurultayı bildirileri, s:489-490.

37. Akal, C., Candan, O., Koralay, O.E., Chen, F. ve Oberhansl1, R. 2007. Afyon Zonu'na Ait Olasılı Erken Triyas Yaşlı Metavolkaniklerin Jeokimyası, Kronolojisi ve Tektonik Ortamları. Türkiye Bilimsel ve Teknolojik Araştırma Kurumu (TÜBİTAK) Projesi No:103Y011.

38. Ustaömer, P.A., Ustaömer, T., Gerdes, A., Robertson, A.H.F. \& Collins, A.S., 2012. Evidence of Precambrian Sedimentation/ Magmatism and Cambrian Metamorphism in the Bitlis Massif, SE Turkey Utilising WholeRock Geochemistry and U-Pb LA-ICP-MS zircon dating. Gondwana Research, 21, 10011018.

39. Okay, A.I., 2011. Tavşanlı Zonu: AnatolidTorid Bloku'nun Dalma-Batmaya Uğramış Kuzey Ucu. MTA Dergisi, 142, 195-226, Ankara. 